\title{
Hjem fra Fronten.
}

Af Andreas Kaad, Mindebjerg, Als.

Det var med bange Anelser, at vi gik Foraaret 1918 imøde. Fra September Maaned - det Tidspunkt hvor jeg kom ud i Etapperne bag Vestfronten som Fangevogter - var der af Fangerne leveret et godt Arbejde for at bygge saa godt et Værn som muligt mod deres Venner men Tyskernes Fjender, mod Ententens Hære. Det Værn, der var bygget syntes uigennemtrængeligt; senere viste det sig jo dog, at det laa inden for Mulighedens Grænser, men at Foraaret vilde blive saare blodigt, stod klart for os alle. Men hvem vilde aabne Offensiven? Hvor og hvornaar vilde Rædselen tage sin Begyndelse. Kunde det ikke tænkes, at Franskmanden vilde bryde igennem netop her, hvor vi var, her i det omstridte Alsace Lorraine, Frankrigs stolte Drømme efter sidste Nederlag i Halvfjerdserne.

Det var en dejlig Foraarsaften i Marts Maaned. En prægtig Solnedgang bød Dagen det sidste Farvel. Da kommer en ung Løjtnant, river Døren op og fortæller glædestraalende: "Hindenburg hat seine Truppen eingesetzt, der eine Sieg folgt dem andern". (Hindenburg har sat sine Tropper ind, den ene Sejr følger efter den anden). Den næste Dags Eftermiddag var jeg paa Vagt i Fangelejren, da Sejrsefterretningerne 
med Meddelelse om Fangernes Antal løb ind. Hvor mange der var taget til Fange husker jeg ikke mere, et stort Antal Englændere var det. Naa, flere end der blev opgivet har der jo sikkert da heller ikke været!!

Først i April Maaned fik jeg Orlov. En Søndag Formiddag var Far og Mor, min Kone og jeg til Gudstjeneste i Sundeved Frimenighed. Thade Petersen holdt en dejlig Prædiken, staar der i min Dagbog fra den Tid. Efter Gudstjenesten stod vi i Smaaklynger uden for Kirken og drøfitede Tidens Begivenheder. Ententens vigende Hære gav en trist Stemning og jeg mindes endnu Fru Dottes ${ }^{1}$ ). "Det er, som om alt gaar os imod $i$ denne Tid, men vi faar tro og haabe».

Foraaret gled, Tyskernes Offensiv bragtes til at standse, ja mere end det. Nu greb Ententens Hære Offensiven, og Tyskernes Hære begyndte at vige Fod for Fod og under en Orlov ved Høsttide i 1918 var Befolkningen meget fortrøistningsfuld. Særlig husker jeg fra den Tid Fars store Optimisme. Forøvrigt: Far og saa min Onkel, nuværende Amtsraadsmedlem Niels Kristensen Nielsen i Miang paa Als nærede end ikke den mindste Tvivl om Krigens endelige Udfald. Da jeg efter Orloven, i September kom tilbage til Garnisonen i Saarburg i Lorraine, var Stemningen blandt Soldaterne meget trykket, og en Meklenborger, der samtidig kom tilbage hjemmefra, ogsaa efter en Orlov, kendetegnede Tyskernes Stilling paa følgende Maade: "Overlever vi de næste tre Maaneder, kan vi holde Jul i Hjemmet. Stillingen er sikkert fortvivlet

1) Frimenighedspræst Jørgen Eriksens Hustru. Præsten selv laa urle ved vestfronten. 
ude ved Fronten, og hjemme i Meklenburg kan Tilstandene slet ikke beskrives."

Jeg kom saa ud til Bønderne som Vagtmand for et Hold russiske Krigsfanger.

Rigskansler Grev Hertling gik, og Rigskansler Prins Max kom, for, som det officielt hed, han skulde "den Frieden anbahnen".

I et tjenstligt Anliggende blev jeg kaldt ind til Bataillonen; det var Søndag Morgen den 6. Oktober, Dagen efter at Prins Max af Baden havde holdt sin Tale i den tyske Rigsdag som Rigskansler, og Fredstilbudet var formet og afsendt til Wilson. Morgenaviserne blev revet bort. "Jetzt kommt wahrhaftig der Friede", sagde to Ynglinge i Officersuniform til hinanden, med Taarer i Øjnene. I flere Eksemplarer tog jeg Efterretningen med ud til Landbefolkningen i Lorraine, hvor jeg var Vagtmand ved et Hold Krigsfanger (Russere). Hvor Befolkningens Øjne lyste. De bar samme Haab i deres Hjerte som vi. AlsaceLorraine-France, Sønderjylland-Danmark. Og Krigsfangernes $\mathrm{Haab}$ om atter at gense deres $\mathrm{Hjem}$ tændtes paany.

Henne paa Kasernen var alt i Opror. Alle var fyldt med Glæde, men man havde tillige Indtrykket af, at man paa ledende Sted ikke var klar over Situationen. Feldwebelen fandt det dog raadeligst at trække "Tropperne" sammen, og endnu samme Dags Eftermiddag fik jeg Ordre til at stille paa Kasernen med de mig undergivne russiske Krigsfanger. Jeg tog tilbage til Landsbyen Brauweiler, hvor jeg snart fandt alle Soldater i Færd med at drøfte Avisernes Nyheder. Om Eftermidldagen drog vi saa afsted fra Brauweiler til en Harmonika's Toner. Russer- 
ne smilte, de havde allerede Færten af, hvad der var i Gære.

Efter et Par Dages Forløb, den 11. Oktober - jeg husker Dagen, fordi det var min Broder Hans's Fødselsdag, om han ikke var falden, havde han den Dag fyldt sit 25. Aar - kom vi ned til Omegnen af Schlettstadt i Alsace, til en Landsby Epfig. Vi blev der, ca. 40 $\mathrm{km}$ bag Fronten, beskæf tiget med at bygge de allerfineste Skyttegrave, trække Pigtraad, grave Jordhuler, der var deres 10-12 Meter dybe og forbundne med hinanden ved underjordiske Gange. Dette Arbejde kunde se ud som Kontrast til Prins Maxes Fredsbud, og jeg husker, at jeg engang spurgte en "fredssikkei" Badenser, hvordan han vilde forklare dette. „Prinz Max wird's machen", var hans Svar. Jeg havde det Indtryk, at Badenserne havde en urokkelig Tro til, at sderes« Prins Max nok skulde faa Freden i Stand.

Indbyggeme var rasende, fordi vi nu saadan paa Slutningen skulde ødelægge deres Vinbjerge, det var ogsaa uforskammet. Forøvrigt havde vi det ellers efter Forholdene rigtig rart, naar undtages, at vi plagedes meget af den spanske Syge, ganske særlig gik det ud over de russiske Krigsfanger, de døde desværre i stort Tal. En mangelfuld Pleje var sikkert Skyld i, at der døde saa mange. Jeg selv laa ogsaa en Uges Tid "til Sengs" og blev plejet af en russisk Læge, og Medicinen bestod af - Aspirintabletter - Aspirintabletter var jo i de Dage Universalmidlet mod alle Sygdomme. Men Forholdene omkring os, hvordan artede de sig? Her var det springende Punkt.

Oplasning var trods alt det Ord, der nu bedst kendetegnede den tyske Hær. Aviserne hjemmefra 
skrev mere og mere aab€nt om alt. Jeg husker særlig et socialdemokratisk Blad, "Schleswig-Holsteinische Volkszeitung", tror jeg, det hed, der blev mere og mere aabenmundet. En Dag stod der med spærret. Tryk foroven paa første Side: "A b ge d a m p $\mathrm{t}$ ! aber nicht abgedankt! Det var Kejseren, da han for sidste Gang som Kejser forlod Berlin, der sigtedes til. En anden Gang mindes jeg, der stod: "Will er - oder will er nicht!« Det var Kejserens Abdication, der fordredes.

Man forstaar, at under disse Forhold blev Tonen blandt Soldaterne ogsaa ret fri, og der var ikke faa, der $\mathrm{i}$ deres Tale anbefalede Kejseren til at tage Cylinderhatten og gaa.

Breve fra Hjemmet naaede ikke mere frem. Den sidste danske Avis, der naaede frem til Fangelejren, var en Hejmdal med H. P. Hanssens Tale $i$ den tyske Rigsdag den 23. Oktober. En Avis i Alsace gav den Karakteren: "Eine schneidige Rede". Bladet har formodentlig været franskvenligt. Ogsaa dette var paa $\sin$ Vis en Hilsen hjemme fra, og sandelig ikke den mindste.

Saa kom den 9. November. Vi trak Pigtraad som besat foran vore nye opkastede Grave, da en Alsinger (Gdr. Jørgen Grau, Melsmark) raabte over til mig: "Kejseren gaar! Hurra!" Det var nok noget forhastet, men at det Øjeblik vilde komme, derom var ingen i Tvivl mere. Da vi efter endt Arbejde kom tilbage til Fangelejren, taltes der kun om den faldno Storhed. Sent paa Aftenen vækkes vi af en Soldat, der har været ved Bataillonen i Saarbourg, han medbragte et Ekstrablad, der med overmaade fede Typer meddelte, at nu var det Alvor. Kejseren var 
færdig. Jeg laa længe vaagen, og Tankerne gik nordover. Det vidste jeg: nu sad de derhjemme or holdt Far's Fødselsdag og fik ganske de samme Ë̈terretninger. Et Kejserriges Fald formaar ikke as slette den Sorg, der netop for 4 Aar siden kom ind ad Hjemmets Dør $\left.{ }^{\star}\right)$. Og saa er dette jo trods alle strenge Kaar den brydende Dag, der melder sig. At det var Slut med Krigen, var vi alle klar over. Og Begivenhederne faldt nu Slag i Slag.

Mandag den 11. November blev der sluttet Vaabenstilstand, og samtidig dannede vi jo Soldaterraad, hvad der unægtelig var en drøj Omgang for d'Hrr. Officerer, alt blev klædt i rødt. Officerer, der ikke med det gode (og det var jo nærmest den, der strittede imod) vilde ombytte deres Kokarde med $\epsilon \mathrm{n}$ tilsvarende rød, blev paa en anden og mindre ve:iskabelig Maade gjort opmærksom paa, at der ingen anden Udvej var.

Krigen som saadan var dermed forbi. Skyndsomst skulde de tyske Tropper trækkes tilbage. Østerrig-Ungarske Tropper havde vi allerede ikke set i nogle Dage; de var jo tidligere falden fra. Ordren lød paa, at vi den 12. November Kl. 11 Formiddag skulde forlade Epfig i Alsace tilligemed vore Fanger. Den sidste Aften blev der holdt Afskedsgilder i Byens Kantiner efter en større Maalestok, og snart gjorde $\varnothing \mathrm{l}$ og Vin deres Virkning. Jeg mindes særlig en ældre Soldat fra Aabenraa. Hjemmetysker efter en

*) Hans Nissen Kaad (Søn af Gaardejer P. Kaad, Vollerup og derines Hustru Anne Kirstine Marie, født Knøs) var født 11. Oktober 1893 i Mindebjerg paa Als og faldt ved Autrêches, Nordfrankrig, den 20. Sept. 1914. Efterretningen naaede først Hjemmet paa Als den 9. November 1914. 
større Maalestok var han. Tysken kunde han imidlertid ikke rigtig komme efter; men forøvrigt en flink Mand. Han kom den Aften i et ganske fortrinligt Humør. Begge to skulde vi paa Vagt den sidste Nat, Jeg fra Kl. 1-3 og han fra Kl. 3-5. Henad 1-Tiden kommer Aabenraa-Manden hjem i Lejren $\mathrm{i}$ en meget løftet Tilstand. Da jeg bliver vaagen, staar han ved Siden af min "Seng« og skraaler af fuld Hals, men sikkert af et godt $\mathrm{Hjærte:} \mathrm{"Vi} \mathrm{er}$ kun faa, men det er det samme«; Hukommelsen svigter ham, og han beder om min Assistance, som jeg meget beredvillig giver ham, og nu gaar den: "Vi er kun faa, men det er samme, - vi er en Gren af den danske Stamme - den visner ej, men den staar i Flor - og bøjer sig mod det høje Niord."

Som Tak for, at han nu vilde lade sin Hjemmetyskhed falde, tog jeg hans Vagt fra 3-5. Han kunde forøvrigt ogsaa nok trænge til al den Ro, han kunde faa, før Marchen begyndte.

Det blev en lang Vagt fra Kl. $1-5$, men ejendommelig. Hele Lejren var falden til Ro. Stjernelyst og stille var det. Ikke et eneste Lysskær mod Vest og ikke nogen Artilleriild. Alt aandede Fred. En Mangfoldighed af Tanker og Billeder drog forbi en. Hvad var der dog ikke sket fra Augustdagene i 1914 og indtil nu. Nu gik det hjemad. Hjem til Kone og Barn; hjem til Far og Mor; hjem til Sønderjylland og hjem til - Danmark. Og dog knugedes man af den Tanke: Hvis der nu skulde komme en Modrevolution; aah ulykkelige Skæbne, om det skulde ske, men man vidste jo aldrig.

Da jeg om Tirsdagen den 12. November om Formiddagen Kl. 10 blev vækket og sad ved min Mor- 
genkaffe«, kom der en Soldat, hjemmehørende i Rostock i Meklenborg hen til mig, og man kunde saa tydelig se, hvor knuget han var af den Skæbne, som Tyskland nu gik ind til, og siger: "Ja, Du kan sagtens være glad, Kaad. I kommer nu tilbage (jeg bed Mærke i Ordet z u r ü c k) til Danmark. Vi bliver ved Tyskland og maa gennemgaa Lidelserne«. Det var forøvrigt samme Mand, der for et Par Maaneder siden havde udtalt de ovennævnte Ord: "Overlever vi de næste tre Maaneder, kan vi holde Jul i Hjemmet«. Han fik Ret, det vilde sikkert nu kunde lade sig gøre.

Klokken 11 stod vi parat. Fanger og Mandskab stillet op i Geled, forud havde vi solgt Lejrbarakkerne til Byens Indbyggere for nogle usle Mark, og saa »støvlede« vi afsted. En slagen Hær paa Flugt! Alt klædt i Rødt, i Revolutionens Tegn. Alle var vi forsynede med den røde Kokarde. Officererne fik deres Gradmærke revet af, og ogsaa de maatte erstatte den sort-rød-hvide Kokarde med en rød.

Vi slutter os under vor Marsch til fremmede Formationer. Der kan ikke være Tale om at komme i Forbindelse med vor Bataillon i Saarbourg. Saa slæntrer da denne Karavane, disse talløse Række:, den slagne Hær hen ad Alsaces Landeveje. I mange Tilfælde er Soldaterne i lasede Uniformer, slet Fodtøj osv. „Og Landets egne, de tapre faa«? - Ja de stod her og der og overalt og viftede os Farvel med Tricoloren, den franske Fane! Aa, hvor man gik og glædede sig! Tricoloren skjulte jo ogsaa paa sin Vis v o r gamle Banner, Danebrog. Ilmarche var det, Franskmændene var jo i Hælene paa os. Den 13. Novbr. Kl. 11,35 Formiddag passerede vi Rhinen. Da vi satte Foden paa Badens Jord, sagde jeg til Jørgen Grau: 
"Lad nu Franskmændene have, hvad der ligger bagved!« De havde saavist fortjent det. Saa var der Hvil i Baden i nogle Dage.

Bare man dog kunde fala Forbindelse med Hjemmet. Det var en Tanke, som stadig trængte sig frem. Meddelelse fra Hjemmet kunde vi selvsagt ikke vente men et Par Ord til dem derhjemme vilde jo sikkert glæde dem mere nu end nogen Sinde. Breve blev ikke ekspederet, det var sagt os. Et Telegram! Jeg forsøgte. Jeg henvendte mig paa Telegrafstationen. Og efterfølgende Ond blev sendt nordpaa »Der Rückzug vollzieht sich in bester Ordnung. Alle wohl. Andreas." Det var et meget dyrt Telegram. men havde selvsagt en god Virkning i Hjemmet. Det var afsendt fra Dundenheim nede i Baden. Der laa vi i nogle Dage til den 17. November for at afvente Transportlejlighed nordpaa. Men Længselen efter Hjemmet var stor som næsten aldrig før. Baden er et dejligt ja ligefrem herligt Land, hvad Naturen angaar. En Aftenstund gik jeg en Tur ganske alene. En dejlig Solnedgang var det $i$ den storslaaede Natur. I Vest Vogesernes høje Tinder og ude i det fjerne Østen den mørke Schwarzwald. Storladen var idet og dog, hvad var det imod det, man nu skulde hjem til. Det var sagt med de faa Ord: ens eget - det danske.

Den 17. November kom vi igen paa Gled. Den 18. afleverede vi de russiske Krigsfanger i en Fangelejr ved Byen Rastatt og endvidere afleverede vi til det derværende Soldaterraad vort Gevær, vor Sabel og Ammunitionen; d e t lettede.

Samme Dags Aften dampede vi nordpaa. Det var den mest eventyrlige Jernbanefart jeg nogensinde har været med til. Togene ganske overfyldt. Her 
kunde man virkelig sige: "Som Sild i en Tønde«. Der var hundekoldt, ituslaaede Ruder i de store Gennemgangsvogne, Polsteret revet af Sæderne i II, og I. Klasses Kupeerne.

Paa Hjemvejen kom vi forbi Slottet Wilhelinshöhe ved Cassel. Hvad var det, den tyske Skolelærer fortalte os: Napoleon, Sedan, Wilhelmshöne! Og nu er Historien gaaet den modsatte Vej.

I Hamborg faar vi de første danske Aviser med Beretningen om det store Folkemøde paa "Folkehjem« den 17. November.

Her paa Hamborgs Banegaard blev man kastet ind i Grænsestriden, men her blev ogsaa Optakten givet til al den lyksalige Tid, der ligger omkring Genforeningen i 1920. Den 21. November naaede vi Neumünster. Herfra blev Hjempermiteringen foretaget den 22. November.

Om Aftenen ved 7-Tiden damper vi videre nordpaa som hjempermitterede. Rendsborg, videre, Slesvig, og videre, Flensborg med Natophold i en tætpakket Ventesal med Hundreder af hjemvendende Nordslesvigere. Næste Dags Morgen videre til Sønderborg og Hjemmet. Og Gensynet! Ja jeg ser endnu Fars store Smil, da jeg mødte ham paa Sønderborg Gade og hører endnu Mors bevægede Stemme i Telefonen, da jeg fra Sønderborg melder: „Hjemme igen«.

Saa med den lille Smaabane op igennem Als. "Velkommen hjem«! lyder det atter og atter. Ved 12Tiden er jeg igen i mit Hjem i Mindebjerg. Og Gensynet i Hjemmet! Ja, det hører Privativet til og kan heller ikke i nogen Form eller Maade gengives. Lykkelig den, der var det beskaaren - at komme hjem! 
Mens disse Linier skrives, er det netop 5 Aar siden, vi oplevede disse bevægede Dage. Og Aar har vi allerede været under dansk Styre. Hver Kirkegaard i Nordslesvig har faaet sin Mindesten over Sognets Faldne, der vidner, hvor store Ofre vi har maattet bringe, men trods al bitter Vé:

Flaget blaffer rødt og hvidt. Her er Danmark, mit og dit med sin Kølvandsstribe.

(Helge Rode i »Moderen«.

Mindebjerg, Als i November 1923.

Andreas Ka a d. 